\title{
Strengthening District Administration in Plural Communal Context: An Analysis of the Potential Impact of Establishing a Kalmunai Administrative District in Sri Lanka
}

\author{
Prof. Dr. Mohammad Agus Yusoff ${ }^{a}$, Dr. Athambawa Sarjoon ${ }^{\text {b*, }}$, and Dr. Zawiyah Mohd Zain ${ }^{c}$ \\ ${ }^{a}$ History, Politics and Security Research Center, Faculty of Social Sciences and Humanities, \\ Universiti Kebangsaan Malaysia, UKM Bangi 43600, Selangor, Malaysia., ' Department of \\ Political Science, University of Peradeniya, Peradeniya 20400, Sri Lanka, 'College of Law, \\ Government and International Studies, Universiti Utara Malaysia, UUM Sintok 06010, \\ Kedah, Malaysia.

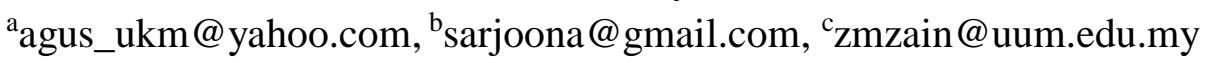

\begin{abstract}
Decentralization promotes and strengthens the quality of local administration in plural communal context. However, decentralized district administration in postindependence Sri Lanka has been challenging, primarily due to a number of issues related to the accommodation of rights and interests of minorities. The persistent sidetracking of minorities' concerns in district administration has pushed them to claim and advocate for separate decentralized institutional arrangements. One such issue is the call to form a separate administrative district (referred to as "Kalmunai administrative district") in the coastal belt of the existing Amparai district. While exploring the factors that motivated the concept of a new administrative district, this study examined the potential impact of the formation of a Kalmunai administrative district. This research employed qualitative and quantitative data collected through different sources, which are presented through interpretive and descriptive arguments. The findings reveal that the conceptualization and advocacy of the Kalmunai administrative district are outcomes of several interconnected factors that undermined the rights and interests of ethnolinguistic minorities in decentralized district administration. These factors include the administrative domination of the ethnic majority, violation of the official language policy, and discrimination and marginalization of ethnic minorities in the district administration affairs. However, this study suggests that the establishment of the proposed administrative district would not only improve the quality of public service delivery and accommodate linguistic concerns of minorities in the district administration but would also enhance the socioeconomic development in the region, if the district administration is carefully organized and managed.
\end{abstract}

Keywords: Decentralized district administration, Kalmunai administrative district, Sri Lanka, Tamil-speaking minorities. 


\section{Introduction}

The decentralization of political and administration processes has traditionally been viewed as a means to resolve conflicts; accommodate ethnoreligious, ethnolinguistic, and regional minorities; and promote public service delivery, economic and regional development, and good governance particularly in countries with plural communal context. However, the Third World experiences with decentralization have generally been marred by disappointment, baring a few successful cases. This situation is primarily attributed to factors related to the integration and accommodation of minorities within the decentralization initiatives. As Rondinelli et al. (1989) pointed out, decentralization processes failed in developing areas due to the lack of strong political and bureaucratic commitment; lack of administrative, institutional, and technical capacity; non-implementation of laws, policies, and provisions; and lack of support from central and low-level government officials. These factors highly influenced the decentralized administration in Sri Lanka too.

Although Sri Lanka has practiced decentralized administrative systems, the accommodation of ethnolinguistic minorities within these systems has continued to be contested. Ethnic minorities still demand for administrative reforms based on decentralization that facilitate public service delivery and other administrative functions at many levels. The demand for the establishment of "Kalmunai administrative district," by carving out the coastal belt of the existing Amparai district in the eastern province, is a long-term issue that basically necessitated the importance of strengthening district administration in the plural communal context.

Thus, this study examined the prospective impact of establishing the proposed Kalmunai administrative district in accommodating ethnolinguistic minorities in the district administrative machinery in Sri Lanka while exploring the root causes for the emergence of the demand. Although establishing the proposed administrative district has a number of effects, this study only examined the contributions of the new district in enhancing district administration, public service delivery, and regional development, thereby accommodating the expectations and aspirations of ethnolinguistic minorities living in the area.

\section{Methodology}

This research is an interpretive case study. Case studies involve the details and intensive analysis of a single case. Case studies also tend to be associated with qualitative research methods. This study capitalized on two forms of data: primary and secondary data collected from different sources. Primary data were gathered through elite interviews with high-level political (12) and administrative officials (21); in-depth semi-structured interviews with selected key informants, including academics and educationist (08), civil activists (06), journalist (02), and general public (08); and focus group discussions with civil actors (04). Personal interviews have several advantages compared with other date collection techniques; hence, it was adopted as the major technique of collecting primary data. Furthermore, relevant institutions, such as Amparai District Secretariat, and 14 Divisional Secretariats of the coastal belt of Amparai district were also consulted to identify deficiencies in conducting public administration and to collect reports and publications related to the core issues of the study. Secondary data were gathered through desk analysis of existing literature available in different forms. 
The primary and secondary data were analyzed and interpreted based on the events and administrative issues pertaining to this study. This paper incorporated only the major data and summaries of other sources that are presented as tables, figures, and interpretive arguments. Interpretive research helps understand people's actions in social situations.

\section{Major findings}

The major findings of this study are summarized under the following subtopics.

\section{Decentralization and Minority Accommodation: Conceptual Analysis}

This research focused on how decentralization, particularly administrative decentralization, helps strengthen district administrations in plural communal context. Therefore, a conceptual analysis was conducted to examine the minority accommodative perspective of decentralization.

Theorists, experts, and practitioners have argued that decentralization reforms and initiatives can be used to ease tension among ethnic groups in plural communal context. By sharing powers with and devolving authority and responsibility to locally established political and administrative bodies, the central government may seem less threatening. Local groups can also settle their grievances with their own mechanisms or with the interference of the central government through decentralized powers and institutions (Yusoff, Sarjoon \& Hassan, 2016a; Lyon, 2013; Gjoni, Wetterberg \& Dunbar, 2010). In this manner, decentralization is a flexible institutional mechanism that accommodates varied concerns and priorities of diverse populations at local-level administration (Siegle \& O’Mahony, 2009). Decentralization also leads to improved service delivery by better matching public services to citizens' needs and preferences and increased innovation as problems are solved at the local level.

Many European experts and policy makers find decentralization as an important way of improving the performance of local governance and civil service to accommodate the interests of diverse groups. In most developing countries in Latin America, decentralization is often viewed as part of a democratization-strengthening process. In many Asian countries, decentralization initiatives were regarded to contribute in improving public service delivery to large populations and accommodating minorities' claims for self-rule and autonomy. However, the degree of decentralization in terms of power and autonomy granted to local units and regionally concentrated ethnolinguistic groups greatly varies across developing countries.

In most less-developed and developing countries, ethnic and religious minorities and communal groups tend to mobilize for decentralized power and autonomy to defend their collective rights and interests and promote their security, status, economic opportunities in development and political-administrative affairs. In Sri Lanka, minority ethnic groups have long been advocating for the decentralization of political, administrative, and fiscal powers to local governments and administrative bodies. Although a number of decentralization initiatives were implemented in post-independence era, most failed to sufficiently accommodate the minorities' rights and expectations due to a number of issues regarding the formation and implementation of decentralization policies and programs. 


\section{Decentralized District Administrative System in Sri Lanka}

The history of modern administration in Sri Lanka started from the beginning of British colonial rule in 1796. In 1833 the British ruler divided Sri Lanka into five administrative provinces for administrative convenience. These provinces were later expanded into 9 provinces, and further sub-divided into 20 administrative districts. Under the British rule, the centralized authority of the government was deconcentrated throughout the country through regional (provincial) and district administrative systems known as Kachcheri system. Under this system, a government agent (now termed as District Secretary) became the chief district administrative official answerable to the central government (Ranasinge, 2014).

Currently, Sri Lanka has 25 administrative districts, all with a long history of development. The latest one is Kilinochchi district, which was formed in 1984 by carving out the selected territories of the southern part of Jaffna district as per the Constitution's Seventh Amendment. In Sri Lanka, districts are third level administrative units next to province and exercise deconcentrated powers of central ministries and departments. A district may be subdivided or amalgamated by a resolution approved by the parliament of Sri Lanka and is further divided into many divisional administrative units.

Although Sri Lanka has a kind of decentralized administrative structure and institutions at different levels, minorities still face a number of issues and challenges in public service access and regional development due to the domination of majority groups and violation of minority rights (Yusoff, Sarjoon, Asrinaldi \& Zain, 2015). Therefore, minority ethnic groups demand and advocate the full implementation of minority rights provisions adopted in the constitution pertaining to public administration and decentralized district administration as to deliver district-level public service easily and effectively. Amparai is one of a contested district in Sri Lanka in which Tamil-speaking minorities have been facing serious issues and challenges in accessing services from district administration from its inception in 1961. Consequently, Tamil-speakers demand and advocate for a separate administrative district for their administrative convenience and other purposes.

District Administration in Amparai and Kalmunai Administrative District Demands: A Background Note

Amparai administrative district was formed on 10 April 1961 by carving out the southern part of Batticaloa district, referred to as the "Kalmunai region," and with the amalgamation of some parts from other districts (Sarjoon, Yusoff, Hussin \& Awang, 2015; Jabbar, 2013). It has been one of the most contested districts in the context of administering ethnically and territorially divided people compared with other districts in Sri Lanka. Amparai district comprises of multiethnic and multilinguistic communities with diverse interests and political and territorial cleavages. Land use, resource distribution, economic development, border limitation, local governance, and language use in public administration became popular issues in district administration (Sarjoon et al., 2015; Mohideen, 2013; Hasbullah, Balasundarampillai \& Silva, 2005). The escalation of the country's ethnic conflict and civil war in the early 1980s further induced the rise of ethnocentric politics and administration in the district. A clear territorial (or regional) demarcation of east-west (or coastal and interior) and an ethnic demarcation of Tamil-speaking and Sinhala-speaking communities within the 
district exist (See: Table 1 \& Figure 1). All these issues played vital roles in the politics and administration of the district and the emergence of administrative issues.

Therefore, for the last five decades, Tamil-speaking communities living in the coastal belt of the Amparai District have been urging government authorities to form a separate administrative district covering three coastal electorates, namely, Kalmunai, Sammanthurai, and Pottuvil in the name of "Kalmunai administrative district." They have been advocated this district as to facilitate the functions of public administration; improve public service delivery; conducts district administration in familiar language; and to enable economic and regional developments. The proposed new district covers an area of 1867.7 square kilometers, which amounts to approximately $40 \%$ of the total land area of the existing Amparai district (Sarjoon et al., 2015; Mohideen, 2013). According to Sri Lanka's 2012 census, the proposed district has a population of 409,260 , which is equivalent to $63 \%$ of the total population of the present Amparai district. Muslims constitute 68.60\%, Tamils 27.40\%, and Sinhalese 3.5\%, as detailed in Figure 1 (Department of Census and Statistics, 2014).

Table 1

Population of Ethnic Groups in Amparai District (2012)

\begin{tabular}{lrr}
\hline Ethnic group & Amount & Percentage \\
\hline Sri Lankan Moors (Muslim) & 281,702 & 43.4 \\
Sinhalese & 252,458 & 38.9 \\
Sri Lankan Tamils & 112,457 & 17.3 \\
Burgers & 1,036 & 0.2 \\
Indian Tamils & 846 & 0.1 \\
Malays & 187 & - \\
Sri Lankan Chetties & 05 & - \\
Others & 711 & 0.1 \\
Total & 649,402 & 100 \\
\hline
\end{tabular}

Source: Department of Census and Statistics, 2014. 
Figure 1

Map and Key Data of the Proposed Kalmunai District

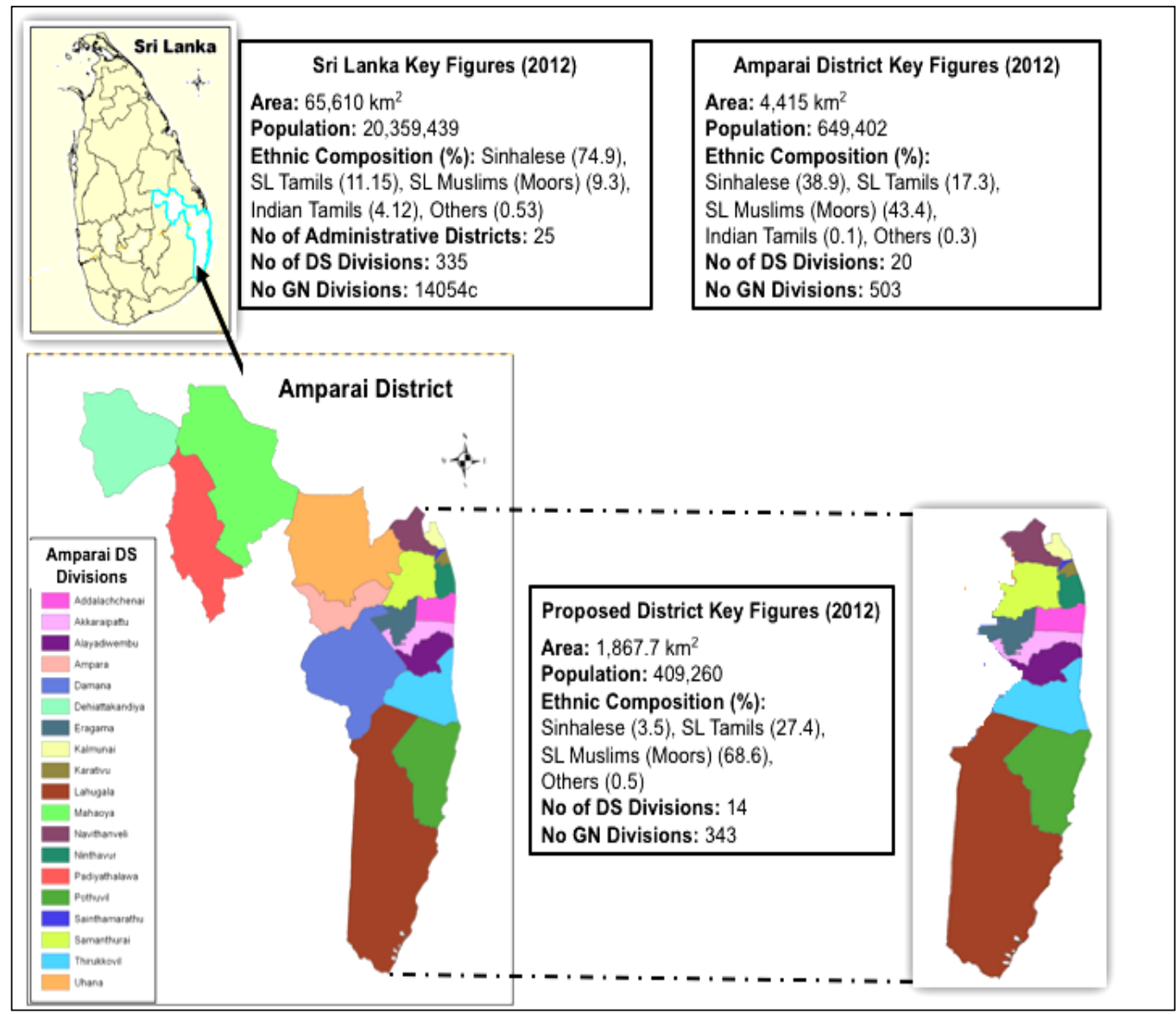

Source: Compiled by the researchers.

\section{Emergence of the Demand}

This study examined the factors that motivated the emergence of the Kalmunai administrative district demand. Accordingly, four major factors caused or induced the people of this region to call for the proposed administrative district. The first factor is the domination of the Sinhalese and Sinhala languages in the daily affairs of Amparai district administration. When the Amparai district was formed, over two-thirds of the district's population were Tamilspeakers, residing on the coastal belt of the district (Sarjoon et al., 2015). However, the District Secretariat and other public institutions were established in the interior part of the district, and they have progressively helped Sinhalese and their language-Sinhala-to dominate the daily affairs of the district administration. Tamil-speakers were not sound in the Sinhala language; hence, this domination considerably restricted them from accessing services from the District Secretariat and public institutions. These issues induced Tamil-speakers to call for a shift in the district administrative machinery to the coastal belt, which is closer to their inhabited area. The continuous negligence of their request pushed them to call for a separate administrative district to their area of residence.

The second factor is the violation of linguistic rights of Tamil-speakers in district administration. Throughout the formation of the Amparai district, Tamil was recognized as the official language in the north-eastern region through the Tamil Language (Special 
Provision) Act (No. 28 of 1958). However, the appointment of the District Secretary and administrative elites from the Sinhalese community resulted in the non-implementation of Tamil as the official language in district administration. Constitutional provisions were later adopted to further legalize Tamil as the official language (Official Languages Commission, 2008). However, the Amparai District Secretariat continued to conduct its daily administration in Sinhala. This situation was in turn viewed by Tamil-speakers as a violation of their language rights, which were ensured in the constitution. The continued sidetrack of their request to conduct the district administration in Tamil language induced them to advocate for a new administrative district hoping that it would reconcile their linguistic issues.

The third factor is the discrimination against Tamil-speakers in district administration affairs. Although Tamil-speakers constituted more than $70 \%$ of the district's population when the Amparai district was formed (at present, it is approximately 61\%), no District Secretary has been appointed for the Amparai District Secretariat from the Tamil-speaking community for the past 57 years. Similarly, the Sinhalese are overrepresented in cadre positions in the district administrative machinery (Sarjoon et al., 2015). The Sinhalese domination has progressively allowed them to take decisions and allocate more resources favoring Sinhalese in a discriminative manner. These ethnic discriminative acts also motivated Tamil-speakers to seriously advocate a separate administrative district concept.

The fourth factor is the marginalization of Tamil-speakers in development and other affairs through the administrative elite and political leadership in the Amparai district. The review of the major development projects implemented in the Amparai district (such as Gal Oya and Gam Udawa) reveals that most development projects were implemented in the interior part of the district, for the benefit of the Sinhalese, whereas Tamil-speakers and their areas lack community and infrastructure development (Yusoff, Sarjoon, Awang \& Handi, 2015). This resulted in increase of Sinhalese and decrease of composition of Tamil-speakers in the district's population and caused land scarcity, and empowering their demand for a separate administrative district. All the above factors and their impact on Tamil-speakers induced the conceptualization and campaign for a separate Kalmunai administrative district.

\section{Rationales and Prospective Impact of Establishing the Proposed Kalmunai District}

This study analyzed the rationales behind the Kalmunai administrative district demand and the positive impact of its establishment particularly on the improvement of functions of district administration, public service delivery, and regional development accommodating the interests and concerns of minorities and communal groups. This study found several reasons justifying the formation of the proposed Kalmunai administrative district. First, demographic factors, such as size of territory and population favor the formation of the new district. Other parts of the country have administrative districts with less territory, population, and administrative divisions than the proposed district. Second, presently, the region has many separate district administrative arrangements, and it is considered a separate administrative area for delivering a number of public services, such as education, healthcare, telecommunication, and judicial events. Third, the proposed district would be an institutional mechanism that can reconcile linguistic concerns originating in the district administration in Amparai. The region is dominated by Tamil-speakers, and the new district is advocated mostly on linguistic background; hence, the daily functions of the district administration 
would be in Tamil language. Fourth, the new district would provide institutional and human capacity to deliver improved public services and enhance economic and regional developments in the region. Fifth, the new district would facilitate district and development administration process in the region, which was severely affected by civil war and natural disasters. The rationales are supported with the following prospective impact of the establishment of the proposed Kalmunai administrative district.

First, public service delivery would be improved. The establishment of the proposed district will enhance the delivery of public services through many means. A new District Secretariat and other decentralized public institutions would be closer to the public and would thus be empowered with sufficient human (mostly Tamil-speaking) and physical resources. This condition would strengthen the institutional and administrative capacity necessary to deliver improved public services. With a separate budgetary allocation, financial sources would be increased to support the necessary administrative and development functions in the region. Moreover, service delivery functions would be made efficient. The problems faced by the public in terms of transportation would be solved, and public services would be accessible in a convenient language (Sarjoon, Yusoff \& Ismail, 2017).

Second, the new district would empower linguistic and other rights of Tamil-speaking minorities. The new district administration would facilitate Tamil-speaking communities to communicate with officers and authorities and fulfill their administrative needs in their own language, without any restrictive barriers. Thus, it would reconcile the grievance of marginalizing the language of Tamil-speakers and the violation of their linguistic rights by the district administrators. The new District Secretariat would ensure the institutional capacity to accommodate minority languages in the administrative machinery. Similarly, the rights of Tamil-speakers to participate in representative bureaucracy would be ensured as the proposed district is established.

Third, the new district would effectively induce progressive economic and regional developments because its establishment would open a new window for budgetary allocation, which can be fully utilized within the district limits for the improvement of infrastructure and socioeconomic conditions. The region has potential resources but have no utilization due to civil war and lack of institutional and financial supports. Thus, the establishment of the proposed district would have a prospective impact on the development of agricultural, tourism, and heritage-based sectors in the region by inducing institutional and financial supports (Yusoff, Sarjoon \& Hassan, 2016b).

In sum, the establishment of the proposed Kalmunai administrative district has a number of beneficial rationales and would positively impact public service delivery, minority rights accommodation, regional development, decentralized administration, and good governance in the region. All these reasons would influence and empower district administration and local politics, but with some negative consequences, including the increase of regionalism and ethnocentric demands. The rationale justifications and proper administration of the new district would challenge the consequences. 


\section{Conclusion}

Decentralization, particularly administrative decentralization, is frequently seen as a means of improving public service delivery and the planning and implementation of development programs and projects by considering local and communal aspirations, needs, and conditions in plural communal context.

Like many developing countries, Sri Lanka too failed to accommodate the concerns and grievances of ethnoreligious minorities in decentralized administrative structures. Particularly, in Amparai district administration, Tamil-speaking communities face a number of challenges in terms of public service access, regional development, and linguistic accommodation. Accordingly, the domination of the majority ethnic group (Sinhalese) and their language (Sinhala), while violating the constitutionally guaranteed minority language (Tamil) rights provisions in district administration together with discriminated and marginalization of ethno-linguistic minorities in district administrative affairs induced number of issues and challenges in accessing services and benefits from district administration. This situation induced these minorities to advocate for decentralized power and institutional arrangement by establishing a district administrative arrangement for their area, in the name of "Kalmunai administrative district."

Although the ethnic majorities and political forces representing them criticize and oppose the proposed Kalmunai district on different grounds, the establishment of the proposed administrative district would improve public service delivery and economic and regional development while accommodating the minorities' concerns and grievances in district administration if it is properly designed and administered. Decentralization initiatives, including policy reform and establishment of institutions and administrative units, are considered by experts and governments as means to accommodate the rights, concerns, and grievances of diverse groups, including minorities. Therefore, Sri Lankan government authorities, bureaucrats, political leaders, and ethnic majorities should focus on the proposed Kalmunai district plan on public service delivery and minority accommodative perspective of decentralized administration. In the post-civil war context, reforming and restructuring district administrative machinery have become highly necessary for improved and efficient public service delivery, regional development, and minority rights accommodation in Sri Lanka.

\section{References}

Department of Census and Statistics. (2014). Census of population and housing-2012 (New) Final report. Colombo: Department of Census and Statistics.

Gjoni, R., Wetterberg, A., \& Dunbar, D. (2010). Decentralization as a conflict transformation tool: The challenge in Kosovo. Public Administration and Development, 30(5), 291312. https://doi.org/10.1002/pad.577

Hasbullah, S.H., Balasundarampillai, P., \& Silva, K.T. (2005). Addressing root causes of the conflict: Land problems in the north-east Sri Lanka. Colombo: Foundation for CoExistence.

Jabbar, M.A. (2013). Creation of new administrative district for Tamil-speaking people in Amparai: A critical analysis. Kalam: Research Journal of Faculty of Arts and Culture, 7, 80-92. 
Lyon, A. (2013). Between the integration and accommodation of ethnic differences: Decentralization in the Republic of Macedonia. Journal on Ethnopolitical Minority Issues in Europe, 11(2), 80-103.

Mohideen, M.I.M. (2013). Eastern muslims must unite politically. Colombo: Al-Ceylan Muslim Documentation Center.

Official Languages Commission. (2008). Language resources need assessment survey 2007/2008. Rajagiriya, Sri Lanka: Official Languages Commission.

Ranasinge, R.A.W. (2014). The role of government agent in local administration in Sri Lanka, International Journal of Education and Research, 2(2), 1-14.

Rondinelli, D.A., McCulluogh, S.S., \& Johnson, R.A. (1989). Analaysis decentralization policies in developing countries: A political economy framework. Development and Change, 20(1), 58-87. https://doi.org/10.1111/j.1467-7660.1989.tb00340.x

Sarjoon, A., Yusoff, M.A., Hussin, N., \& Awang, A. (2015). The demand for an administrative district for the costal belt of Amparai district in Sri Lanka: An assessment of its root causes. Mediterranean Journal of Social Sciences, 6(4S3), 434443.

Sarjoon, A., Yusoff, M.A., \& Ismail, M.A. (2017). Public service delivery: Impact of establishing an administrative district in the Kalmunai region, Sri Lanka. International Business Management, 11(4), 929-940. 10.3923/ibm.2017.929.940

Siegle J., \& O’Mahony. P. (2009). Assessing the merits of decentralization as a conflict mitigation strategy. Decentralization and democratic governance handbook. Washington, DC: United States Agency for International Development (USAID).

Yusoff, M. A., Sarjoon, A., Asrinaldi., \& Zain, Z. M (2015). Decentralized administration and minority accommodation in Sri Lanka: Analyzing status, issues, challenges and prospects. Mediterranean Journal of Social Sciences, 6(4S1), 533-542. 10.5901/mjss.2015.v6n4s1p533

Yusoff, M. A., Sarjoon, A., Awang, A., \& Hamdi, I. H. (2015). Land policies, land-based development programs and the question of minority rights in eastern Sri Lanka. Journal of Sustainable Development, 8(8), 223-233. http://dx.doi.org/10.5539/jsd.v8n8p223

Yusoff, M.A., Sarjoon, A., \& Hassan, M.A. (2016a). Decentralization as a tool for ethnic diversity accommodation. Journal of Politics and Law, 9(1):55-64. http://dx.doi.org/10.5539/jpl.v9n1p55

Yusoff, M.A., Sarjoon, A., \& Hassan, M.A. (2016b). An analysis of the development impacts of establishing Kalmunai administrative district in Sri Lanka. Journal of Sustainable Development, 9(1), 164-176. http://dx.doi.org/10.5539/jsd.v9n1p164 